\title{
Artikel
}

\section{Omgevingsfondsen bij wind- en zonneparken}

\author{
Pecunia non olet?
}

Mr. D.E. (Dorien) Bakker en prof. mr. H.D. (Hanna) Tolsma*

\section{Inleiding}

'Hoe verdeel je een windfonds? Omwonenden en dorpen komen er na drie jaar niet uit'; 'Omwonenden zijn niet blij met verdeling windfonds'; 'Duidelijke boodschap aan windboeren: "Maak het geld over en hou op"'; 'Omwonenden Kijlsterweg in Stadskanaal balen: wel een zonnepark in de achtertuin, maar gebiedsfonds komt niet met compensatie over de brug'. ${ }^{1}$

$\mathrm{Nu}$ de komst van omvangrijke wind- en zonneparken op land onvermijdelijk is, wordt met bovenstaande berichtgeving in lokale nieuwsbladen een nieuwe strijd geillustreerd: die van een eerlijke verdeling van de lusten en de lasten bij duurzame energieprojecten. De nieuwsberichten zien op omgevingsfondsen bij wind- en zonnepar-

* Mr. D.E. Bakker is in 2021 afgestudeerd aan de Rijksuniversiteit Groningen. Prof. mr. H.D. Tolsma is hoogleraar Besluitvorming en rechtsbescherming in het omgevingsrecht aan de Rijksuniversiteit Groningen). Dorien Bakker schreef ter afsluiting van de master Nederlands Recht, onder begeleiding van Hanna Tolsma, de scriptie 'Omgevingsfondsen bij wind- en zonneparken: met (wettelijke) waarborgen omgeven?' De scriptie vormt de basis voor deze bijdrage.

1. RTV Noord, Hoe verdeel je een windfonds? Omwonenden en dorpen komen er na drie jaar niet uit, 29 september 2020, te vinden op: www.rtvnoord.nl; RTV Noord, Omwonenden niet blij met verdeling windfonds, 9 november 2020, te vinden op: www.rtvnoord.nl; RTV Drenthe, Duidelijke boodschap aan windboeren: 'Maak het geld over en hou op', 5 februari 2021, te vinden op: www.rtvdrenthe.nl; DvhN, Omwonenden Kijlsterweg in Stadskanaal balen: wel een zonnepark in de achtertuin, maar gebiedsfonds komt niet met compensatie over de brug, 22 februari 2021, te vinden op: www.dvhn.nl. ken. Omgevingsfondsen worden opgericht om de omgeving te laten meeprofiteren van een duurzaam project. $^{2}$ Een omgevingsfonds wordt doorgaans gevuld met gelden van de projectontwikkelaars om vervolgens onder maatschappelijke doelen te worden verdeeld, bijvoorbeeld ten behoeve van de aanleg van glasvezel, een wijkfeest of verlichting van een parkeerplaats bij een dorpshuis. ${ }^{3}$ Aangezien een wettelijke regeling omtrent omgevingsfondsen ontbreekt, staat het de betrokken partijen in grote mate vrij om de vormgeving van een omgevingsfonds te bepalen. ${ }^{4}$

In de berichtgeving wordt doeltreffend weergegeven dat dit betrekkelijk nieuwe fenomeen in gemeenschappen tot controverse kan leiden. De artikelen gaan over de (op te richten) omgevingsfondsen bij Windpark Geefsweer, Windpark De Drentse Monden en Oostermoer en Zonnepark Stadskanaal. Bij Windpark Geefsweer was een klankbordgroep opgericht om regels te creëren voor het verdelen van de gelden. Na drie jaar was het deze klankbordgroep nog niet gelukt om tot overeenstemming te komen. Toen een gedeputeerde van de provincie Groningen op verzoek de knoop doorhakte, leidde ook die keuze tot onvrede. Bij een ander project, namelijk Windpark De Drentse Monden en Oostermoer, wensten de 'windboeren' zeggenschap te krijgen over de verdeling van de gelden uit het op te richten omgevings-

2. Hier opgewekt, Lokale Energiemonitor 2019, februari 2020, te vinden op: www.hieropgewekt.nl, p. 57.

3. 'Afgeronde projecten 2016', te vinden op: www.windfondsdelfzijlnoord.nl; 'Omgevingsfonds', te vinden op: www.windparknijmegenbetuwe.nl.

4. Participatiewaaier 2019, te vinden op: www.klimaatakkoord.nl (laatst geraadpleegd op 3 juni 2021), p. 5. 
fonds. De vertegenwoordigers van de omwonenden wilden geen bemoeienis van de initiatiefnemers. Om de impasse de doorbreken, werd ook hier de overheid gevraagd om spelregels te bedenken. ${ }^{5}$ Bij Zonnepark Stadskanaal waren er verdelingsregels, maar klaagden omwonenden over een gebrek aan transparantie van deze regels.

Hoewel in de gegeven voorbeelden gedoe is ontstaan door de komst van een omgevingsfonds, is het omgevingsfonds juist bedoeld om draagvlak voor duurzame energieprojecten te bevorderen. Omwonenden zijn vaak fel tegen de komst van een wind- of zonnepark, wat een belemmering voor een voortvarende energietransitie kan vormen. Door omwonenden vroegtijdig te betrekken bij een energieproject wenst de overheid draagvlak te vergroten en zo (juridische) weerstand te voorkomen. ${ }^{6}$ In het Klimaatakkoord zijn daarom afspraken gemaakt over zogenoemde procesparticipatie en financiële participatie. ${ }^{7}$ Procesparticipatie strekt tot inhoudelijke betrokkenheid van omwonenden bij het besluitvormingsproces. $\mathrm{Bij}$ financiële participatie investeren omwonenden in het project of ervaren omwonenden (ook) voordelen van de opbrengsten uit het project. Ter uitwerking van het Klimaatakkoord beschrijft de Participatiewaaier verschillende opties van financiële participatie, zoals mede-eigenaarschap in de vorm van een coöperatie, financiële deelneming door middel van obligaties of een omwonendenregeling. ${ }^{8}$ Ook het omgevingsfonds is onderdeel van de mogelijkheden. ${ }^{9}$

Het omgevingsfonds is sterk in opkomst. Vrijwel alle plannen voor windparken voorzien in een omgevingsfonds. Hoewel het oprichten van een omgevingsfonds bij zonneparken minder gangbaar is, wordt het instrument langzaamaan ook in die sector geïntroduceerd. ${ }^{10}$ Ook onder decentrale overheden zijn omgevingsfondsen geliefd. In participatiebeleid zijn meerdere voorbeelden te vinden van pogingen om projectontwikkelaars te dwingen of aan te moedigen een omgevingsfonds te vullen. ${ }^{11}$ In bestaande literatuur is echter meermaals geconstateerd dat het huidige en toekomstige omge-

5. RTV Drenthe, Provincie aan de slag met spelregels gebiedsfonds molenpark, 19 februari 2021, te vinden op: www.rtvdrenthe.nl.

6. Klimaatakkoord, 28 juni 2019, te vinden op: www.klimaatakkoord.nl, p. 216.

7. Klimaatakkoord, 28 juni 2019, p. 164 en 219.

8. Bij een omwonendenregeling ontvangen individuele huishoudens een voordeel, zoals korting op groene stroom. Participatiewaaier, te vinden op: www.klimaatakkoord.nl (laatst geraadpleegd op 3 juni 2021).

9. In rechtspraak en literatuur komen we verschillende benamingen tegen, zoals 'gebiedsfonds', 'windfonds' en 'duurzaamheidsfonds'. In de praktijk wordt dikwijls een omwonendenregeling onder de noemer 'gebiedsfonds' geschaard. Het omgevingsfonds en de omwonendenregeling worden dan als een pakket aangeboden. Deze bijdrage gaat in aansluiting op de Participatiewaaier uit van het 'omgevingsfonds' zonder een omwonendenregeling

10. Hier opgewekt 2020, p. 41, 56 en 81

11. Zie bijv. Provincie Groningen, Beleidskader Sanering en opschaling, gebiedsfonds en participatie, 29 januari 2014, te vinden op: www.provinciegroningen.nl, p. 19; Gemeente Rotterdam, Beleidskader Windenergie, 8 mei 2018, te vinden op: www.rotterdam.nl, p. 5 en 7; Gemeente Utrecht, Uitnodigingskader Rijnenburg en Reijerscop, juli 2020, te vinden op: www.utrecht.nl, p. 25 en 27. vingsrecht geen grondslag biedt om financiële participatie af te dwingen. ${ }^{12}$

Het groeiend aantal omgevingsfondsen, evenals de problemen die blijken uit bovenstaande berichtgeving zijn voor ons reden het omgevingsfonds juridisch onder de loep te leggen. Het omgevingsfonds roept prangende vragen op. Wat is een omgevingsfonds? Welke regels gelden (niet) in het kader van omgevingsfondsen? Welke actoren hebben zeggenschap over een omgevingsfonds? Wie bepaalt welke projecten maatschappelijk relevant zijn? Welke waarborgen gelden voor een eerlijke verdeling? De centrale vraag in deze bijdrage luidt: in hoeverre kent het huidige juridische kader regels over zeggenschap en waarborgen voor een eerlijke verdeling van gelden uit omgevingsfondsen?

Eerst beschrijven we het instrument 'omgevingsfonds', mede op basis van een verkenning van de praktijk (par. 2). Daarna schetsen we het juridisch kader (par. 3), waarbij onder meer wordt onderzocht of en wanneer de beheerder van een omgevingsfonds kan worden aangemerkt als een bestuursorgaan. Indien een bestuursorgaan bepaalt welke projecten financiering krijgen, heeft dit belangrijke gevolgen voor de toepasselijke regelgeving en waarborgen (publiek of louter privaat?). Vervolgens gaan we dieper in op het vraagstuk zeggenschap (par. 4) en de waarborgen voor een eerlijke verdeling (par. 5). We sluiten af met een conclusie (par. 6).

\section{Omgevingsfondsen in de praktijk}

In deze paragraaf brengen we de feitelijke kenmerken van een omgevingsfonds in kaart. Dit is nodig om het instrument vervolgens juridisch te duiden en het juridisch kader te schetsen. De vormgeving van een omgevingsfonds verschilt van geval tot geval. We schetsen in grote lijnen de gemeenschappelijke feitelijke kenmerken op het gebied van planvorming en oprichting, financiën, beheer en verdeling. De beschrijving van het omgevingsfonds in de Participatiewaaier vormt hierbij de basis. Ook benoemen we de verschillen tussen omgevingsfondsen in de praktijk. ${ }^{13}$

\subsection{Planvorming en oprichting}

Een omgevingsfonds komt in beginsel voort uit afspraken tussen 'de ontwikkelaar' en 'de omgeving'. ${ }^{14}$ In het Klimaatakkoord is afgesproken dat het bevoegd gezag controleert dat de projectontwikkelaars met de omgeving in gesprek gaan over financiële participatie. De wij-

12. H.D. Tolsma, Procesparticipatie en financiële participatie bij wind- en zonneparken, JBplus 2021, p. 67-81; A.G. Bregman \& J.J. Karens, Financiële participatie en omgevingsbijdragen bij zonneparken. Van bestuurlijke wens tot afdwingbare eis, TBR 2020/118.

13. De bevindingen zijn gebaseerd op een oriënterend onderzoek naar de praktijk van omgevingsfondsen bij wind- en zonneparken. In het bijzonder is dat onderzoek toegespitst op de omgevingsfondsen bij de windparken Delfzijl-Noord, Nijmegen-Betuwe en Wieringermeer.

14. Participatiewaaier 2019, p. 9. 
ze waarop deze controle plaats dient te vinden, wordt in het Klimaatakkoord niet nader geduid. Wie is 'de omgeving'? Het kan gaan om een ongeorganiseerde groep van omwonenden die met de projectontwikkelaar een verplichting tot afdracht van winst aan een omgevingsfonds is overeengekomen. Ook komt voor dat een klankbordgroep wordt opgericht om invulling aan het omgevingsfonds te geven. Klankbordgroepen beslissen bijvoorbeeld over de precieze besteding van en de zeggenschap over de middelen. ${ }^{15}$ Daarnaast kan een bewonersplatform zich als gesprekspartner aandienen. ${ }^{16}$ Deze organisaties bestaan uit omwonenden.

Een bewonersplatform is vaak mede gericht op het vinden van vertegenwoordigers die plaats willen nemen in de zogenoemde omgevingsadviesraad (ook wel genoemd omgevingsraad). In de omgevingsadviesraad zijn in beginsel alle betrokken partijen vertegenwoordigd, te weten overheden, omwonenden, belangenorganisaties en meestal ook projectontwikkelaars. De omgevingsadviesraad wordt opgericht om onder meer een omgevingsovereenkomst tot stand te brengen. ${ }^{17}$ In de omgevingsovereenkomst worden afspraken gemaakt over bijvoorbeeld de maximale geluidproductie, verlichting, beperking van slagschaduw en financiële participatie, zoals de oprichting van een omgevingsfonds. Bij grote energieprojecten wordt soms voor de uitvoering van de gemaakte afspraken een uitvoeringsorganisatie in het leven geroepen. Een voorbeeld hiervan is Stichting Windloket in het kader van het Windpark Wieringermeer. ${ }^{18}$

\subsection{Financiën}

Een omgevingsfonds wordt in beginsel gevuld met gelden afkomstig van de projectontwikkelaars. ${ }^{19}$ De gedragscode 'Acceptatie \& Participatie Windenergie op Land' van de Nederlandse WindEnergie Associatie (NWEA) noemt een richtbedrag van $€ 0,40$ tot 0,50 per megawattuur (MWh). Doorgaans wordt deze richtlijn aangehouden, maar bij coöperatieve initiatieven is de afdracht vaak beduidend hoger. ${ }^{20}$ De projectontwikkelaars van Windpark Nijmegen-Betuwe betalen bijvoorbeeld $€ 1$ per MWh. ${ }^{21}$ Ook komt een jaarlijkse afdracht van een vast bedrag voor. Zo wordt in het 'Windfonds Delfzijl-Noord' gedurende vijftien jaar jaarlijks $€ 50.000$ gestort. $^{22}$

15. Bijv. bij Windpark Geefsweer, RTV Noord 9 november 2020.

16. NPBO, Het betrekken van burgers bij de energietransitie, 2019, te vinden op: www.npbo.nl, p. 16.

17. NLVOW, Handboek Omgevingsparticipatie bij windenergie op land. Lessen uit de praktijk, 2017, te vinden op: www.nlvow.nl, p. 40.

18. NLVOW 2017, te vinden op: www.nlvow.nl, p. 49.

19. Participatiewaaier 2019, p. 9.

20. Zie Noordelijke Rekenkamer, Verdeling onder hoogspanning. Een onderzoek naar de verdeling van kosten en baten rondom wind- en zonneparken, Groningen, maart 2020, te vinden op: www.noordelijkerekenkamer.nl, p. 10.

21. Zie art. 7 lid 2 van Reglement Omgevingsfonds Windpark NijmegenBetuwe, te vinden op: www.windparknijmegenbetuwe.nl (laatst geraadpleegd op 21 juni 2021).

22. Zie art. 1 lid 2 van Fondsreglement Windfonds Delfzijl-Noord, te vinden op: www.windfondsdelfzijlnoord.nl (laatst geraadpleegd op 18 juni 2021).

In het onderzoeksrapport 'Verdeling onder hoogspanning' heeft de Noordelijke Rekenkamer geconstateerd dat de gerealiseerde financiële participatie sterk per casus verschilt. De onderzoekers concluderen dat de totstandkoming van financiële participatie afhankelijk is van onzekere factoren, zoals welke bestuurslaag het bevoegd gezag is, wat de onderhandelingsvaardigheden van omwonenden zijn, hoe zij ondersteund worden en wat de bereidheid is van initiatiefnemers om de eisen te accepteren. ${ }^{23}$ Ook door decentrale overheden gehanteerde beleidskaders kunnen tot verschillen leiden. Provincie Groningen beweegt ontwikkelaars tot een jaarlijkse afdracht van $€ 1050$ per opgestelde megawatt $(\mathrm{MW}){ }^{24}$ Het hanteren van het NWEA-richtbedrag levert echter meer geld voor een omgevingsfonds op. ${ }^{25}$

Dat significante verschillen tussen projecten bestaan, blijkt ook als we een vergelijking maken tussen de omvang van drie omgevingsfondsen. Zo zien we bijvoorbeeld een groot verschil tussen de omgevingsfondsen bij de windparken Delfzijl-Noord, NijmegenBetuwe en Wieringermeer. Het verschil in totale afdracht kan wel oplopen tot $€ 16.000$ per opgestelde MW (zie tabel 1). ${ }^{26}$

Het komt voor dat naast de projectontwikkelaars ook de overheid een bedrag in een omgevingsfonds stort. Zo heeft het Rijk in het kader van Windpark De Drentse Monden en Oostermoer 'bij wijze van uitzondering' een financiële bijdrage van $€ 2,1$ miljoen aan het omgevingsfonds geleverd. Daarnaast heeft het Rijk de provinciale bijdrage verdubbeld naar $€ 180.000$ per jaar. ${ }^{27}$ Dat het Rijk gelden stort in het omgevingsfonds kan worden verklaard door de onrust die de komst van het windpark heeft veroorzaakt. Met de bijdrage wordt beoogd een positieve impuls aan het gebied te geven en daarmee het vertrouwen van de inwoners te herstellen. ${ }^{28}$ Ook de gemeenten Aa en Hunze en Borger-Odoorn storten in het fonds. Bij elkaar opgeteld gaat het om een bedrag van ongeveer $€ 4,7$ miljoen aan overheidsgeld dat in de loop van tien jaar in het omgevingsfonds wordt geinvesteerd.

\subsection{Beheer}

Het beheer van een omgevingsfonds is in handen van een beherende entiteit die verschillende vormen kan aannemen, zoals een lokale coöperatie, stichting, dorp, bewonersvereniging of omgevingsadviesraad. Doorgaans bij de desbetreffende windparken weer. Mogelijk zijn ook andere vormen van financiële participatie bewerkstelligd. Om deze reden kan de tabel een vertekend beeld geven van de omvang van de algehele financiële participatie. Voor zover bekend zijn er behalve de omgevingsfondsen, de omwonendenregeling bij Windpark Wieringermeer en het lokaal eigendom bij Windpark Nijmegen-Betuwe geen andere vormen van financiële participatie tot stand gekomen.

27. Kamerstukken II 2019/20, 33 612, nr. 72

28. Kamerstukken II 2019/20, 33 612, nr. 72. 
Tabel 1 Omvang omgevingsfondsen bij mindparken Delfzijl-Noord, Nijmegen-Betume en Wieringermeer

\begin{tabular}{|c|c|c|c|c|c|}
\hline Windpark & $\begin{array}{r}\text { Totaal vermogen } \\
\text { in } \mathrm{MW}\end{array}$ & $\begin{array}{r}\text { Jaarlijkse afdracht } \\
\text { in } €\end{array}$ & $\begin{array}{r}\text { Looptijd in } \\
\text { jaren }\end{array}$ & $\begin{array}{r}\text { Jaarlijkse afdracht } € / \\
M W\end{array}$ & Totale afdracht $€ / \mathrm{MW}$ \\
\hline Delfzijl-Noord & 62,7 & $50.000,00$ & 15 & 797,45 & $11.961,72$ \\
\hline Nijmegen-Betuwe & 10 & $22.000,00$ & 9 & $2.200,00$ & $19.800,00$ \\
\hline Wieringermeer & $300-400$ & $100.000,00$ & 15 & $250,00-333,33$ & $3.750,00-5.000,00$ \\
\hline $\begin{array}{l}\text { Wieringermeer incl. } \\
\text { omwonendenregeling }\end{array}$ & $300-400$ & 529.000 & 15 & $1.322,50-1.763,33$ & $19.837,50-26.449,95$ \\
\hline
\end{tabular}

betreft het een stichting met ANBI-status. ${ }^{29}$ Er wordt een onafhankelijk bestuur benoemd, waarin in ieder geval een vertegenwoordiging van de omwonenden zetelt. ${ }^{30}$ De doelstellingen van het omgevingsfonds - vastgelegd in de statuten - zien vaak op het bijdragen aan de duurzaamheid en de leefbaarheid in een specifiek gebied. ${ }^{31}$ In een enkel geval voert een gemeente het beheer over een omgevingsfonds. Zo wordt vanuit Windpark Hazeldonk jaarlijks een bedrag afgedragen aan het Klimaatfonds Breda. ${ }^{32}$ Uit dit fonds worden op aanvraag leningen verstrekt ten behoeve van projecten die bijdragen aan de klimaatdoelen van de stad.

\subsection{Verdeling}

De beherende entiteit verdeelt de gelden uit het omgevingsfonds onder de indieners van een verzoek hiertoe. ${ }^{33}$ Zij doet dit op basis van een fondsreglement. Een fondsreglement bevat onder meer indieningsvereisten, beoordelingscriteria en een selectieprocedure voor verzoeken. Zo bepaalt het wie een project kan indienen, bijvoorbeeld: 'inwoners van de dorpen en non-profitorganisaties gevestigd in de gemeente Delfzijl'. ${ }^{34}$ Daarnaast bakent het fondsreglement het werkgebied van het omgevingsfonds af. Het kan voorkomen dat gelden worden verstrekt in de vorm van een lening, zoals met het Klimaatfonds Breda geschiedt. Ook is mogelijk dat een omgevingsfonds wordt ingericht als 'revolverend fonds' ${ }^{35}$ Een dergelijk fonds bevat ten minste voor een deel publiek geld. Financiering wordt dan verstrekt met de bedoeling dat het uitgeleende geld na verloop van tijd weer terugvloeit. ${ }^{36}$

29. Hier opgewekt 2020, p. 57.

30. Participatiewaaier 2019, p. 9

31. Bijv. art. 4 Fondsreglement Windfonds Delfzijl-Noord en art. 2 Reglement Omgevingsfonds Windpark Nijmegen-Betuwe.

32. Hier opgewekt 2020, p. 57; zie ook 'Klimaatfonds Breda', www.breda.nl.

33. Hier opgewekt 2020, p. 57.

34. Art. 5 lid 1 Fondsreglement Windfonds Delfzijl-Noord.

35. Zo wordt verwacht dat bij Windpark De Drentse Monden en Oostermoer een revolverend fonds onderdeel gaat uitmaken van de financiële participatie, zie hiervoor: RTV Drenthe, Afspraken bewoners Aa en Hunze en windpark Veenkoloniën in zicht, 23 juli 2020, te vinden op: www.rtvdrenthe.nl; DvhN, Omgevingsadviesraad zet stappen. ‘Helft van het geld gebiedsfonds windpark Drentse Monden en Oostermoer is voor burenregeling. Ook voor mensen in Stadskanaal-Noord', 3 februari 2021, te vinden op: www.dvhn.nl.

36. J.E. van den Brink, Realistisch revolveren. Het revolverend fonds met een Europese touch, Deventer: Wolters Kluwer 2018, p. 11

\section{Juridisch kader}

De bovengeschetste omgevingsfondsen bij wind- en zonneparken komen voort uit privaatrechtelijke afspraken. ${ }^{37}$ Geen wet verplicht tot de oprichting van een omgevingsfonds, bevat een definitie of stelt eisen aan de vormgeving ervan. In deze paragraaf staat het juridisch kader centraal. Eerst komt de verhouding tot wettelijke instrumenten aan de orde: planschadevergoeding (afdeling 6.1 van de Wet ruimtelijke ordening (Wro)) en de financiële bijdrage voor ruimtelijke ontwikkeling (art. 6.24 lid 1 onder a Wro). Hierbij richten we de aandacht met name op het verschil in ratio tussen het omgevingsfonds en deze publiekrechtelijke instrumenten. Vervolgens gaan wij na welke normen van toepassing zijn op een omgevingsfonds. Bepalend is of de beheerder van het fonds aangemerkt kan worden als bestuursorgaan.

\subsection{Afbakening instrumentarium Wro}

Hoe verhoudt financiële participatie van de omgeving in een energieproject - en in het bijzonder de investering van een initiatiefnemer in een omgevingsfonds - zich tot het recht op planschade? ${ }^{38}$ Art. 6.1 Wro geeft benadeelden van een planologische wijziging een recht op planschadevergoeding voor zover de schade redelijkerwijs niet voor rekening van de aanvrager behoort te blijven en de tegemoetkoming niet voldoende anderszins is verzekerd. Een vraag is of de tegemoetkoming in de schade met een omgevingsfonds 'voldoende anderszins verzekerd' is. Van Zundert wijst erop dat in plaats van compensatie door omwonenden wordt gekozen voor participatie. ${ }^{39}$ Ook Feltz en Olivier benoemen dat financiële participatie via de band van schade die 'anderszins is verzekerd', dient mee te wegen in de omvang van vergoedbare schade. Wel benadrukken zij daarbij dat dit niet als een automatisch proces moet worden gezien:

'Enige wetenschap bij de participanten zal aanwezig moeten zijn (Vgl. ABRvS 30 november 2016,

37. Participatiewaaier 2019, p. 4-5 en 9.

38. Zie uitgebreid over compensatie van schade bij windturbines $L$. Tichelaar, Kunnen omwonenden van windturbines eventuele gezondheidsschade en waardedaling van hun woning gecompenseerd krijgen?, AA 2019, afl. 11, p. 865-874

39. J.W. van Zundert, Windmolens: wind- en zonneparken, BR 2018/56, p. 352. 
ECLI:NL:RVS:2016:3196, r.o. 5.2) en zal er in de praktijk overigens ook vrijwel altijd zijn. Zij zullen immers willen weten waarin zij participeren. ${ }^{40}$

Wij zijn van mening dat het storten van gelden in een omgevingsfonds in beginsel geheel losstaat van planschadevergoeding. De ratio van de oprichting van een omgevingsfonds is veeleer gelegen in de wens de omgeving te laten meeprofiteren van de komst van een windof zonnepark door financiering van maatschappelijke projecten. Het gaat niet om de vergoeding van individueel geleden schade. Dit neemt overigens niet weg dat bij besluitvorming (ook) afspraken over de vergoeding van planschade tot stand kunnen komen.

Het door de initiatiefnemer storten van gelden in een omgevingsfonds vertoont raakvlakken met de financiële bijdrage voor ruimtelijke ontwikkeling die het bevoegd gezag van een initiatiefnemer van een planologische wijziging kan verlangen op grond van art. 6.24 lid 1 onder a Wro. ${ }^{41}$ Met deze bijdrage bekostigt het bevoegd gezag maatregelen ten behoeve van vooraf in een structuurvisie vastgelegde ruimtelijk relevante waarden, zoals natuur, landschap en recreatie. Zo kan bijvoorbeeld in een structuurvisie met het oog op de publieke waarde 'het toeristisch-recreatief aanbod binnen de gemeente' worden vastgelegd dat het wijzigen van een recreatiebestemming naar een woonbestemming leidt tot het onttrekken van objecten aan het recreatieve aanbod. Ter compensatie van dit verlies van een recreatief object wordt van de eigenaar verlangd een financiële bijdrage in een fonds te storten waaruit door de gemeente maatregelen worden bekostigd om het toeristisch-recreatief product in de gemeente te verbeteren. De financiële bijdrage voor ruimtelijke ontwikkeling is in dat geval bedoeld als compensatie van een inbreuk door een project op die ruimtelijk relevante waarde, die is vastgesteld in beleid. Dat maakt ook het verschil duidelijk met het in het kader van een wind- of zonnepark opgerichte omgevingsfonds. De ratio van een omgevingsfonds is immers niet zozeer gelegen in het compenseren van genoemde waarden, maar in het laten meeprofiteren door de omgeving van het project.

\subsection{Bestuursrecht}

In hoeverre zijn bestuursrechtelijke normen relevant in het kader van een omgevingsfonds? Als een bestuursorgaan betrokken is bij de totstandkoming en vormgeving van een omgevingsfonds, dan is de Algemene wet bestuursrecht (Awb) in elk geval ten dele van toepassing. Via art. 3:1 lid 2 Awb jo. art. 3:14 van het Burgerlijk Wetboek (BW) zijn bestuursorganen immers ook

40. ABRvS 24 januari 2018, ECLI:NL:RVS:2018:219, O\&A 2018/4 m.nt. G.C.W. van der Feltz en R. Olivier.

41. Uit jurisprudentie volgt dat als een initiatiefnemer weigert vrijwillig een dergelijke privaatrechtelijke (anterieure) overeenkomst aan te gaan, het bestuur planologische medewerking aan het project kan weigeren als dat niet bijdraagt aan een goede ruimtelijke ordening (art. 3.1 lid 1 Wro), zie ABRvS 28 augustus 2019, ECLI:NL:RVS:2019:2950, AB 2020/41 m.nt. H.D. Tolsma, BR 2019/87 m.nt. M. Fokkema, TBR 2019/141 m.nt. A.G. Bregman (Recreatiewoning Oldebroek). gebonden aan de geschreven en ongeschreven regels van het publiekrecht wanneer zij privaatrechtelijk handelen. Dit betekent dat een bestuursorgaan te allen tijde de algemene beginselen van behoorlijk bestuur in acht moet nemen, zoals het zorgvuldigheidsbeginsel. ${ }^{42}$

Opvallend is dat in fondsreglementen regelmatig de term 'subsidies' wordt gehanteerd. ${ }^{43}$ Is de subsidieregeling uit de Awb van toepassing op de verdeling van de gelden uit een omgevingsfonds? Is de beslissing op een verzoek om financiering uit het fonds een besluit in de zin van art. 1:3 Awb, waartegen rechtsbescherming openstaat bij de bestuursrechter? Dit is het geval als de beherende entiteit van het omgevingsfonds aangemerkt kan worden als bestuursorgaan. In een enkel geval wordt het beheer door 'de gemeente' gevoerd, zoals bij het Klimaatfonds Breda. In 2014 heeft de gemeenteraad het Klimaatfonds opgericht. ${ }^{44}$ Het college van $\mathrm{B} \& \mathrm{~W}$ is bevoegd leningen te verstrekken uit door de gemeenteraad gevormde fondsen. ${ }^{45} \mathrm{Nu}$ een bestuursorgaan van de gemeente over de gelden beslist, is daarop de Awb met de subsidieregeling (titel 4.2) van toepassing. ${ }^{46}$

Doorgaans is de beherende entiteit een privaatrechtelijke stichting. Uit de rechtspraak volgt dat privaatrechtelijke rechtspersonen die geldelijke uitkeringen of op geld waardeerbare voorzieningen aan burgers verstrekken, aangemerkt kunnen worden als bestuursorgaan (in de zin van art. 1:1 lid 1 onder b Awb) als aan twee cumulatieve eisen is voldaan. ${ }^{47}$ Van een dergelijk buitenwettelijk bestuursorgaan is sprake indien 'de inhoudelijke criteria voor het verstrekken van geldelijke uitkeringen of voorzieningen in beslissende mate worden bepaald door een of meer bestuursorganen als bedoeld in art. 1:1, lid 1, aanhef en onder a, van de Awb' en 'de verstrekking van deze uitkeringen of voorzieningen in overwegende mate, dat wil zeggen in beginsel voor twee derden of meer, wordt gefinancierd door een

42. Zie ook art. 3:14 BW. Zie voorts HR 27 maart 1987, ECLI:NL:HR: 1987:AG5565 (Amsterdam/Ikon); HR 24 april 1992, ECLI:NL:HR: 1992:ZC0582 (Zeeland/Hoondert); HR 26 april 1996, ECLI:NL:HR: 1996:ZC2051 (Rasti Rostelli).

43. Bijv. art. 4 lid 9 Reglement Omgevingsfonds Windpark Nijmegen-Betuwe. 'Het Windfonds', zie hiervoor NLVOW 2017, onder 'richtlijnen'.

44. Raadsbesluit en Raadsvoorstel van 18 december 2014, Gemeente Breda, nr. 42845, te vinden op: www.stadsarchief.breda.nl.

45. 'Besluit van het college van burgemeester en wethouders en de burgemeester van de gemeente Breda houdende regels omtrent mandaat Algemeen Mandaatbesluit Breda 2019', te vinden op: www.lokaleregelgeving.overheid.nl, Bijlage: schema B, onder 'financiering en betalingsverkeer'. Uit navraag is gebleken dat de Directeur Ruimtelijk Economisch Domein op dit punt gemandateerd is. Voor ons is niet duidelijk of de gemeenteraad een subsidieregeling heeft vastgesteld met betrekking tot het Klimaatfonds. Hoofdstuk 14 van de Nadere regels subsidieverstrekking gemeente Breda 2017 bevat voorwaarden voor klimaatprojecten. De leningen verstrekt uit het Klimaatfonds lijken hier niet onder te vallen.

46. Zie art. 4:21 Awb.

47. ABRvS 17 september 2014, ECLI:NL:RVS:2014:3379, AB 2015/129 m.nt. H. Peters, JB 2014/202 m.nt. L.J.M. Timmermans (Stichting bevordering kwaliteit leefomgeving Schipholregio), r.o. 5.1; ABRvS 17 september 2014, ECLI:NL:RVS:2014:3394, AB 2015/130 m.nt. H. Peters, JB 2014/203 m.nt. L.J.M. Timmermans (Stichting Platform 31). 
of meer bestuursorganen in de zin van art. 1:1, lid 1, aanhef en onder a Awb'.

Meestal worden de inhoudelijke criteria voor verdeling vastgesteld door het bestuur van de privaatrechtelijke entiteit of de omgevingsadviesraad. Soms zijn overheden expliciet uitgesloten van het bestuur. ${ }^{48}$ Ook als overheden wel vertegenwoordigd zijn, is niet zonder meer sprake van 'zeggenschap in beslissende mate'. Mocht in een concreet geval wel voldaan zijn aan het inhoudelijke vereiste, dan staat waarschijnlijk het financiële vereiste in de weg aan de kwalificatie als bestuursorgaan. In de praktijk dragen overheden slechts in uitzonderlijke gevallen bij aan een omgevingsfonds. Bovendien dient de overheidsbijdrage twee derde of meer van de totale financiering te bedragen. Zelfs als de overheid een substantieel bedrag bijdraagt, zoals in het kader van het Windpark De Drentse Monden en Oostermoer ( $€ 4,7$ miljoen), wordt deze hoge financiële lat niet gehaald. De projectontwikkelaars storten namelijk ook gelden in het fonds (naar schatting $€ 3.375 .000$ ). Toepassing van de criteria uit de rechtspraak op de praktijk leidt dus tot de conclusie dat de beherende entiteit in de regel niet als bestuursorgaan kan worden aangemerkt.

Uit het voorgaande blijkt dat de constructie van een omgevingsfonds bepalend is voor de toepasselijkheid van bestuursrechtelijke normen. Het onderscheid tussen een beherende entiteit die kan worden aangemerkt als bestuursorgaan en een beherende entiteit die niet als zodanig kan worden gekwalificeerd, heeft verstrekkende consequenties voor de waarborgen bij verdeling van omgevingsfondsen. De gevolgen komen tot uitdrukking in de normering van transparantie, toezicht en rechtsbescherming (zie verder par. 5).

\subsection{Privaatrecht}

De totstandkoming van omgevingsfondsen is afhankelijk van het maken van afspraken. Dit proces wordt beheerst door het privaatrecht. $\mathrm{Nu}$ in de praktijk de beherende entiteit in de regel niet is gebonden aan de Awb of een specifieke (wettelijke) regeling, wordt ook de uitvoering van omgevingsfondsen beheerst door het privaatrecht. Hierbij valt allereerst te denken aan het vermogensrecht. ${ }^{49}$ Als uitgangspunt in het vermogensrecht geldt de contractsvrijheid van partijen, waardoor het niet veel richting geeft aan de totstandkoming en de uitvoering van omgevingsfondsen. ${ }^{50}$ Aangezien de meeste beherende entiteiten de rechtsvorm van een stichting hebben, is daarnaast het stichtingsrecht relevant. De wet, statuten en reglementen bepalen het interne recht van stichtingen. ${ }^{51}$ Met name de statuten (inclusief de statu-

48. Bijv. art. 6 lid 2 en 2 lid 7 Fondsreglement Windfonds Delfzijl-Noord

49. Op grond van art. 2:5 BW zijn rechtspersonen aan te merken als rechtssubject, waardoor deze rechten en plichten kunnen dragen.

50. J. Hijma, C.C. van Dam, W.A.M. van Schendel \& W.L. Valk, Rechtshandeling en overeenkomst (Studiereeks Burgerlijk Recht 3), Deventer: Wolters Kluwer 2016, p. 13.

51. C.H.C. Overes, T.J. van der Ploeg \& W.J.M. van Veen, Dijk/Van der Ploeg. Van vereniging en stichting, coöperatie en onderlinge waarborgmaatschappij, Deventer: Kluwer 2013, p. 75. taire doelstelling) en het fondsreglement gelden als richtsnoeren voor het bestuur van de stichting. De wet geeft sancties voor het handelen in strijd met de statuten, het fondsreglement en het overschrijden van de statutaire doelstelling. ${ }^{52}$ De inhoud van de statuten en het fondsreglement zijn dus van groot belang voor een duidelijke en eerlijke procedure voor de verdeling van omgevingsfondsen.

\section{Zeggenschap over omgevingsfondsen}

Een belangrijke vraag uit de praktijk is welke partijen zeggenschap over een omgevingsfonds (moeten of kunnen) hebben. De omwonenden van het energieproject, de projectontwikkelaars en overheden kunnen allen invloed uitoefenen. In deze paragraaf stellen wij onduidelijkheden en knelpunten omtrent de zeggenschap over omgevingsfondsen vast. Eerst bespreken wij algemeen voorkomende onduidelijkheden hieromtrent (par. 4.1). Vervolgens besteden wij aandacht aan zeggenschap over de hoogte van de afdracht aan omgevingsfondsen (par. 4.2). Tot slot gaan wij in op de vraag wie zeggenschap heeft over de verdeling van de gelden (par. 4.3).

\subsection{Algemeen}

De in de inleiding besproken strubbelingen over de omgevingsfondsen bij de windparken Geefsweer en De Drentse Monden en Oostermoer vloeien voort uit het vraagstuk van de zeggenschap. Welke actoren mogen de verdelingsregels vaststellen? Mogen de projectontwikkelaars (mee)bepalen? Hoe kan men patstellingen doorbreken? Richtsnoeren hierover ontbreken echter. Het antwoord op de vraag wie (uiteindelijke) zeggenschap heeft over de keuze voor een omgevingsfonds en de invulling hiervan is afhankelijk van de lokale context. In de totstandkomingsfase van een project wordt gekozen voor een bepaalde vorm van financiële participatie en wordt een regeling hieromtrent opgesteld. Zo moeten afspraken worden gemaakt over de omvang van het fonds, het beheer en de criteria voor de verdeling van de gelden. In het Klimaatakkoord en de Participatiewaaier wordt benadrukt dat ieder project maatwerk vereist, waardoor de gewenste (financiële) participatie en invulling daarvan per project kunnen verschillen. ${ }^{53}$ Om dezelfde reden heeft de wetgever ervan afgezien om in de Omgevingswet regels te stellen ten aanzien van (financiële) participatie. ${ }^{54}$ Uit het Klimaatakkoord volgt een verplichting voor de projectontwikkelaar om een proces te doorlopen, opdat men komt tot een 'wenselijke en haalbare vormgeving van participatie'. De mogelijkheden hiervoor worden genoemd in de Participatiewaaier. Het bevoegd gezag dient te controleren of de project-

\footnotetext{
52. Zie hiervoor art. 2:7, 2:14 en 2:15 onder c BW.

53. Klimaatakkoord, 28 juni 2019, p. 26; Participatiewaaier 2019, p. 4.

54. Klimaatakkoord, 28 juni 2019, p. 26; Kamerstukken II 2013/14, 33962 , nr. 3, p. 39, 208, 217 en 277 (MvT).
} 
ontwikkelaar met 'de omgeving' in gesprek is gegaan. ${ }^{55}$ Concrete aanwijzingen voor dit proces worden niet gegeven.

Het ontbreken van richtsnoeren leidt in de praktijk tot langslepende discussies. ${ }^{56}$ De situaties die zich voordoen bij de windparken Geefsweer en De Drentse Monden en Oostermoer zijn niet uniek. De NLVOW, de belangenvereniging voor omwonenden van windturbines, constateert dit knelpunt in een rapport met ervaringen uit de praktijk. De auteurs merken op dat al gauw niet alleen controverse ontstaat over het windpark, maar ook over het omgevingsfonds. Zo kan controverse ontstaan over de hoogte van de jaarlijkse afdracht aan het fonds en de samenstelling van het bestuur. ${ }^{57}$

\subsection{Jaarlijkse afdracht}

Wat betreft de hoogte van de jaarlijkse afdracht, is in het Klimaatakkoord vastgelegd dat een eventueel op te richten omgevingsfonds 'met een voor het project redelijk bedrag wordt gevuld door de initiatiefnemer(s), waarbij de hoogte van de bedragen uit de NWEA-gedragscode als richtlijn wordt gehanteerd'. ${ }^{58}$ De richtlijn voor afdracht aan een omgevingsfonds wordt dus bepaald door de energiebranche, die belang heeft bij een lage afdracht. Consequentie hiervan is dat de omwonenden in een slechte onderhandelingspositie verkeren wanneer zij een grotere afdracht wensen. Zo schrijft Rietveld dat met de komst van de NWEA-gedragscode voor omwonenden geen onderhandelingsruimte op financieel vlak meer bestaat. Het bedrag uit de gedragscode is echter niet gestaafd met feiten of voortgekomen uit consensus met omwonenden. ${ }^{59}$ Omdat projectontwikkelaars niet door het publiekrecht worden verplicht tot afdracht aan een omgevingsfonds, zou men kunnen stellen dat het logisch is dat zij zelf kunnen bepalen of en welk bedrag zij wensen af te dragen. Met het oog op uniformiteit valt aan te prijzen dat door de energiebranche een richtbedrag is vastgesteld. Het Klimaatakkoord en de Participatiewaaier onderstrepen echter dat (de invulling van) financiële participatie voortkomt uit een gesprek met de omgeving. ${ }^{60}$ Hierbij past niet goed dat de omvang van een eventueel omgevingsfonds in feite reeds door de energiebranche is vastgesteld.

\subsection{Bestuurbeherende entiteit}

Wanneer eenmaal een omgevingsfonds met een beherende entiteit is opgericht, rijst de vraag welke personen deze gaan besturen. In het Klimaatakkoord staat hierover dat de besluitvorming over de besteding van het omgevingsfonds door de omgeving geschiedt. Ook uit de Participatiewaaier volgt dat in het onafhankelijk bestuur in ieder geval een vertegenwoordiging van de

55. Klimaatakkoord, 28 juni 2019, p. 164.

56. Zie bijv. ook DvhN, Lastig om aan wensen van alle betrokkenen tegemoet te komen. Geld uit gebiedsfonds Oosterhorn toch voor een deel naar maatschappelijke projecten, 18 maart 2021, te vinden op: www.dvhn.nl.

57. NLVOW 2017, p. 47

58. Klimaatakkoord, 28 juni 2019, p. 165.

59. R. Rietveld, De omgevingsraad, dat is de oplossing, NLVOW 2015.

60. Klimaatakkoord, 28 juni 2019, p. 164; Participatiewaaier 2019, p. 3. omwonenden zetelt. ${ }^{61}$ Dat de omgeving beslist over de verdeling van een omgevingsfonds, is in de praktijk echter niet vanzelfsprekend. Zo zit in het bestuur van de stichting bij het omgevingsfonds van Windpark Wieringermeer slechts één omwonende. Verder hebben afgevaardigden van Windcollectief Wieringermeer (de gezamenlijke projectontwikkelaars), de projectontwikkelaars Vattenfall en ECN, gemeente Wieringermeer, een penningmeester, een voorzitter en een secretaris zitting in het bestuur. ${ }^{62}$ Het bestuur van de stichting is dus sterk verbonden met de projectontwikkelaars. Het is voorstelbaar dat de bemoeienis van de projectontwikkelaars frustratie opwekt bij omwonenden, aangezien hun geen daadwerkelijke zeggenschap over het omgevingsfonds wordt gegeven. Onafhankelijkheid van de projectontwikkelaars wordt niet geëist in bindende regelgeving, in de NWEA-gedragscode of in andere stukken. Daadwerkelijke zeggenschap van omwonenden bij de verdeling van omgevingsfondsen is dus niet verzekerd.

\section{Waarborgen bij de verdeling van omgevingsfondsen}

In het voorgaande hebben wij besproken dat op de verdeling van omgevingsfondsen in de praktijk doorgaans noch de Awb, noch een specifieke regeling van toepassing is. Gelden dan nog voldoende waarborgen voor een eerlijke verdeling? In deze paragraaf gaan wij eerst in het algemeen in op de (al dan niet) toepasselijke waarborgen en de noodzaak hiervan. Vervolgens leggen wij de focus op een aantal specifieke waarborgen, namelijk transparantie, toezicht en rechtsbescherming.

\subsection{Algemeen}

Doordat de beherende entiteiten, meestal stichtingen, in de praktijk doorgaans niet kunnen worden aangemerkt als bestuursorgaan, zijn deze vervolgens niet gebonden aan het geschreven en ongeschreven bestuursrecht. ${ }^{63}$ Art. 3:1 lid 2 Awb en art. 3:14 BW bieden geen uitkomst, aangezien de civiele rechter deze slechts toepast op rechtspersonen krachtens publiekrecht ingesteld. ${ }^{64}$ Beginselen en bepalingen uit het bestuursrecht, die normalerwijs vrijwel zeker hadden bijgedragen aan een eerlijke verdeling, zijn dus niet van toepassing. ${ }^{65}$ Het ontbreken van bestuursrechtelijke

61. Klimaatakkoord, 28 juni 2019, p. 165; Participatiewaaier 2019.

62. 'Hoofdlijnen Stichtingsakte Windloket', zie hiervoor NLVOW 2017, p. 128-129.

63. Zie P.J. Huisman \& F.J. van Ommeren, Hoofdstukken van privaatrechtelijk overheidshandelen. Publiekrechtelijke en privaatrechtelijke rechtspersonen op de grens van publiek- en privaatrecht, Deventer: Wolters Kluwer 2019, p. 225 en 237

64. W. den Ouden, Het coöperatieve bestuursorgaan, NTB 2016/52, par. 4 .

65. Zo geldt de subsidietitel, titel 4.2 Awb, niet. Ook de normen die gelden voor schaarse subsidies zijn dan niet van toepassing (zie ABRvS 11 juli 2018, ECLI:NL:RVS:2018:2310, AB 2018/406 m.nt. J.E. van den Brink en A. Drahmann en ABRvS 2 november 2016, ECLI:NL:RVS: 2016:2927, AB 2016/426 m.nt. C.J. Wolswinkel). 
waarborgen knelt te meer indien publieke gelden aan een omgevingsfonds worden afgedragen, zoals bij Windpark De Drentse Monden en Oostermoer geschiedt. ${ }^{66}$ Immers, de subsidietitel van de Awb is ingesteld om (onder meer) waarborgen te creëren bij publieke financiering met maatschappelijke doeleinden. ${ }^{67}$ Door publieke gelden te laten verdelen door een privaatrechtelijke entiteit die geen bestuursorgaan is, wordt deze regulering ontlopen. De nadelige gevolgen van het ontbreken van publiekrechtelijke waarborgen illustreren we door dieper in te gaan op de stand van zaken wat betreft transparantie, toezicht en rechtsbescherming. Daarbij bespreken wij ook de al dan niet aanwezigheid van privaatrechtelijke waarborgen.

\subsection{Transparantie}

Het doel van een omgevingsfonds is het creëren van draagvlak en acceptatie onder de omwonenden van een energieproject. Hiervoor is van belang dat omwonenden inzicht kunnen krijgen in de wijze waarop de verdeling tot stand komt en zich (uiteindelijk) hierin kunnen vinden.

Voor de verstrekking van subsidies geeft de Awb zowel voorafgaand aan de verstrekking als na afloop ervan een verplichting tot transparantie. Uit art. 4:26 Awb volgt dat de wijze waarop subsidies met een subsidieplafond worden verdeeld wettelijk moet zijn bepaald. De verdelingsregels dienen voorafgaand aan de aanvraagperioden te worden vastgesteld en bekendgemaakt. ${ }^{68}$ Deze eis vloeit voort uit het rechtszekerheidsbeginsel. Aanvragers kunnen zo weten wat zij van hun aanvraag kunnen verwachten. Op grond van art. 3:46 en 3:47 Awb moet een besluit rusten op een deugdelijke motivering, die bij de bekendmaking van het besluit moet worden gegeven. $\mathrm{Nu}$ de beherende entiteit doorgaans niet is gebonden aan de Awb, is deze in beginsel niet verplicht om verdelingsregels bekend te maken of haar verdeling van een (deugdelijke) motivering te voorzien. Kunnen omwonenden wellicht toch transparantie verwachten, bijvoorbeeld op grond van een fondsreglement?

In de onderzochte fondsreglementen zijn beoordelingscriteria opgenomen. ${ }^{69}$ Uit deze criteria kunnen aanvragers een mate van rechtszekerheid putten, mits deze

66. Kamerstukken II 2019/20, 33 612, nr. 72. Zie J. van den Brink \& W den Ouden, Van regel naar uitzondering. Over hoe de Algemene wet bestuursrecht veel 'subsidierelaties' niet of nauwelijks normeert, in: A.T. Marseille e.a. (red.), 25 jaar Awb. In eenheid en verscheidenheid, Deventer: Wolters Kluwer 2019, p. 213-223.

67. W. den Ouden, M.J. Jacobs \& N. Verheij, Subsidierecht (Mastermonografieën staats- en bestuursrecht), Deventer: Kluwer 2011, par. 1.1-1.3. 'Publiek geld verplicht', zie hiervoor Raad voor de financiële verhoudingen, Tussen betalen en bepalen. Publieke bekostiging van maatschappelijk perspectief, november 2014, te vinden op: www.raadopenbaarbestuur.nl, par. 2.2; J.E. van den Brink \& W. den Ouden, De subsidie nieuwe stijl, NJB 2016/2000.

68. Denkbaar is bijv. een tendersysteem, waarbij op basis van kwalitatieve criteria een rangorde wordt gemaakt. Zie C. Borman, commentaar op art. 4:26 Awb, aant. 3, in: T.C. Borman e.a., Tekst \& Commentaar Algemene wet bestuursrecht, Deventer: Wolters Kluwer 2020

69. 'Beoordelingscriteria', te vinden op: www.windfondsdelfzijlnoord.nl; art. 4 Reglement Omgevingsfonds Windpark Nijmegen-Betuwe; 'Het Windfonds', zie hiervoor NLVOW 2017, p. 119-120. helder en bindend zijn geformuleerd. Bij het lezen van fondsreglementen komt men echter veel vage criteria tegen, zoals 'voldoende draagvlak', 'activerend werken' en 'leefbaarheid'. In de stukken wordt vervolgens niet tot nauwelijks ingevuld op welke wijze dient te worden getoetst of aan deze criteria is voldaan. In het fondsreglement bij 'Omgevingsfonds Windpark NijmegenBetuwe' is zelfs expliciet benoemd dat het oordeel van de 'Stichting' discretionair is, waardoor het bestuur in hoge mate vrij is een afweging te maken. ${ }^{70}$ Indien is voldaan aan alle voorwaarden uit het fondsreglement en het verzoek goed scoort op de beoordelingscriteria, kan de aanvraag dus alsnog worden afgewezen. Op deze wijze geven de beoordelingscriteria de indieners nauwelijks rechtszekerheid.

Vervolgens is niet gewaarborgd dat de afwijzing gemotiveerd dient te worden. Het afleggen van verantwoording na een verdeling kan worden verplicht door het fondsreglement, maar dit is niet vanzelfsprekend. Zo is in het fondsreglement bij 'Windfonds Delfzijl-Noord' een verplichting voor het 'Stichtingsbestuur' opgenomen om na elke ronde verantwoording af te leggen over de selectie en dat publiekelijk te communiceren. Voorts volgt uit dit fondsreglement een verplichting om jaarlijks de inwoners van de omliggende dorpen, het college van $B \& W$ en Eneco over de wijze van besteding van de gelden uit het omgevingsfonds te informeren. ${ }^{71}$ Het fondsreglement bij 'Omgevingsfonds Windpark Nijmegen-Betuwe' sluit een verantwoordingsverplichting daarentegen uitdrukkelijk uit:

'De stichting is geen verantwoording verschuldigd over en kan niet aansprakelijk worden gehouden voor haar keuzen, besluiten en werkwijzen, echter zij dient in overeenstemming te handelen met het Fondsreglement. ${ }^{72}$

De indieners kunnen daardoor geen inzicht eisen in de wijze waarop de verdeling heeft plaatsgevonden.

\subsection{Toezicht}

Ook indien de statuten en het fondsreglement concreet en voldoende gedetailleerd zijn vormgegeven, is de naleving ervan nog niet verzekerd. Ondanks dat in een omgevingsfonds jaarlijks tienduizenden, soms wel honderdduizenden euro's omgaan, waaronder incidenteel ook publieke gelden, verplicht geen publiekrechtelijke regeling tot het instellen van een toezichthoudend orgaan. ${ }^{73}$ Het stichtingsrecht voorziet evenmin in een toezichthoudend orgaan. ${ }^{74}$ Art. 2:297a en 2:297b BW impliceren slechts de mogelijkheid om een raad van toezicht in het leven te roepen, maar verplichten daartoe

70. Art. 5 lid 4 Reglement Omgevingsfonds Windpark Nijmegen-Betuwe.

71. Art. 6 lid 5 en 8 lid 5 Fondsreglement Windfonds Delfzijl-Noord.

72. Art. 5 lid 8 Reglement Omgevingsfonds Windpark Nijmegen-Betuwe.

73. Zie bijv. tabel 1 .

74. G.J.C. Rensen, Mr. C. Assers Handleiding tot de beoefening van het Nederlands burgerlijk recht. 2. Rechtspersonenrecht. Deel III. Overige rechtspersonen, Deventer: Wolters Kluwer 2017/347a. 
niet. ${ }^{75}$ Door toezicht te houden en het bestuur te adviseren kan een raad van toezicht bijdragen aan een eerlijke verdeling. Worden omgevingsfondsen, ondanks het ontbreken van een verplichting hiertoe, in de praktijk van een toezichthoudend orgaan voorzien?

Of een toezichthoudend orgaan in het leven wordt geroepen, hangt wederom ervan af of de betrokken actoren dit afspreken. De noodzaak van een toezichthoudend orgaan neemt toe wanneer publieke gelden deel gaan uitmaken van een omgevingsfonds. Bij het omgevingsfonds van Windpark De Drentse Monden en Oostermoer wordt dan ook met het oog op publieke verantwoording en toezicht op de gelden een raad van toezicht ingesteld. ${ }^{76}$ Ook bij het omvangrijke 'Windfonds Wieringermeer' is een raad van toezicht opgericht, die bestaat uit overheden en initiatiefnemers. ${ }^{77}$ Het fondsreglement bij 'Windfonds Delfzijl-Noord' voorziet daarentegen niet in een toezichthoudend orgaan. Bij 'Omgevingsfonds Windpark Nijmegen-Betuwe' lijkt toezicht zelfs te zijn uitgesloten door de bepaling dat geen verantwoording is verschuldigd. ${ }^{78}$ Zolang geen toezicht door de statuten of het fondsreglement wordt gewaarborgd, kunnen eigenlijk enkel omwonenden aan de bel trekken in geval van wanbestuur. Hiermee komen we aan bij de vraag naar rechtsbescherming.

\subsection{Rechtsbescherming}

Kan een organisatie of omwonende een beslissing tot verdeling van een omgevingsfonds aanvechten, indien deze beweerdelijk ten onrechte geen aanspraak kan maken op een bedrag uit het fonds? Doorslaggevend is of de beherende entiteit al dan niet aangemerkt kan worden als bestuursorgaan. In de praktijk betreft de beherende entiteit doorgaans geen bestuursorgaan. Een beslissing ter zake van de verdeling van een omgevingsfonds is dan geen besluit in de zin van art. 1:3 Awb. Het maken van bezwaar tegen een dergelijke beslissing is dientengevolge uitgesloten, evenals het instellen van beroep bij de bestuursrechter. ${ }^{79}$

Als bestuursrechtelijke rechtsbescherming ontbreekt, resteert de burgerlijke procesgang. De burgerlijke rechter fungeert als 'restrechter' ${ }^{80}$ Een indiener die na een teleurstellende verdeling een eis instelt, zal echter doorgaans geen grondslag hebben op basis waarvan de rechter zijn vordering kan toewijzen. Er is geen overeenkomst die recht geeft op een uitkering en er is geen onrechtmatige daad gepleegd door geen uitkering toe te kennen. Een bedrag uit een omgevingsfonds blijft immers een vrijwillige bijdrage die slechts aan een (aantal) indiener(s) toekomt. Daarnaast zijn de procedures voor verdeling, zoals die volgen uit de fondsregle-

75. M.J. van Uchelen-Schipper, De rol en positie van de raad van toezicht van de stichting (Uitgave vanwege het Instituut voor Ondernemingsrecht, deel 112), Deventer: Wolters Kluwer 2018, par. 4.3.4, 5.3.2 en 5.3.6.

76. DvhN 3 februari 2021

77. 'Het Windfonds', zie hiervoor NLVOW 2017, p. 119

78. Art. 5 lid 8 Reglement Omgevingsfonds Windpark Nijmegen-Betuwe.

79. Art. $1: 5$ lid 1 en 3 jo. art. 8:1 Awb.

80. Huisman \& Van Ommeren 2019, p. 694. menten, doorgaans vaag geformuleerd, waardoor met het volgen van de procedure niet automatisch een aantal projecten als winnaar uit de bus komt. Het bestuur behoudt discretie bij de verdeling van de gelden uit het omgevingsfonds. ${ }^{81}$

Een vordering uit onrechtmatige daad ex art. 6:162 BW is denkbaar, maar wordt enkel toegewezen als er daadwerkelijk een onrechtmatige daad is gepleegd. Denk bijvoorbeeld aan een bestuur dat steekpenningen ontvangt voor het uitkeren van een bedrag aan een dubieuze organisatie, terwijl een andere organisatie, die anders evident aanspraak had kunnen maken op de gelden, achter het net vist. Van dergelijke onbetamelijke handelingen zal echter vrijwel nooit sprake zijn. Daarnaast kan het aantonen van de geleden schade problematisch zijn, aangezien de indiener alleen een 'extraatje' misloopt.

Kan het rechtspersonenrecht dan nog een grondslag bieden om een onterechte afwijzing teniet te doen? Gedacht kan worden aan een aantal wettelijke sancties. Zo zijn besluiten genomen in strijd met de wet of de statuten ingevolge art. 2:14 BW nietig. Besluiten genomen in strijd met het fondsreglement zijn vernietigbaar op grond van art. 2:15 onder c BW. Voorts is een rechtshandeling waarmee de statutaire doelstelling wordt overschreden ingevolge art. 2:7 $\mathrm{BW}$ vernietigbaar, indien de wederpartij wist of moest weten dat het doel overschreden werd. Echter, deze bepalingen bieden de teleurgestelde indieners waarschijnlijk evenmin soelaas. Voor het inroepen van art. 2:14 en 2:15 onder c BW moet het gaan om een privaatrechtelijk besluit, wat niet elke rechtshandeling van een orgaan van de stichting betreft. ${ }^{82}$ Daarnaast moet de indiener een redelijk belang hebben bij zijn of haar vordering. ${ }^{83}$ Aangezien de indiener vanwege de vage termen in de fondsreglementen en de discretie van het bestuur niet per definitie aanspraak kan maken op een bedrag uit het omgevingsfonds, kan sterk worden betwijfeld of hieraan wordt voldaan. Ten slotte kan doeloverschrijding ex art. 2:7 BW alleen door de rechtspersoon worden ingeroepen, waardoor aanvragers zich hier niet in rechte op kunnen beroepen. ${ }^{84}$

$\mathrm{Nu}$ bestuursrechtelijke en privaatrechtelijke rechtsbescherming in beginsel ontbreekt, zal rechtsbescherming tegen oneerlijke verdelingen wederom afhankelijk zijn van de inhoud van het fondsreglement. De onderzochte fondsreglementen voorzien echter niet in een geschillenregeling. In het fondsreglement bij 'Omgevingsfonds Windpark Nijmegen-Betuwe' is zelfs

81. Zie par. 5.2 en bijv. art. 5 lid 4 Reglement Omgevingsfonds Windpark Nijmegen-Betuwe.

82. De vergadering van het orgaan moet geldig zijn bijeengeroepen, waarvan de meerderheid van de leden over het besluit heeft gestemd. Daarnaast moet het gaan om beslissingen die een wijziging tot stand brengen in het interne recht van de rechtspersoon of in de rechtsbetrekkingen met anderen. Zie Overes e.a./Dijk/Van der Ploeg 2013, p. 97-99.

83. Overes e.a./Dijk/Van der Ploeg 2013, p. 97-99 en 114.

84. J. Roest, commentaar op art. 2:7 BW, in: H.B. Krans, C.J.J.M. Stolker \& W.L. Valk (red.), Tekst \& Commentaar Burgerlijk Wetboek, Deventer: Wolters Kluwer 2020 
expliciet opgenomen dat de beslissingen in beginsel bindend zijn voor indieners. ${ }^{85}$ Waarschijnlijk zal de indiener die het oneens is met de verdeling van het omgevingsfonds dus met lege handen staan.

\section{Conclusie}

Een omgevingsfonds als vorm van financiële participatie biedt mooie kansen om de omgeving van wind- en zonneparken een positieve impuls te geven. De bestaande omgevingsfondsen hebben reeds bijgedragen aan waardevolle maatschappelijke projecten. De betrokken overheidslagen, maatschappelijke partijen en de energiebranche hebben met het Klimaatakkoord het belang van financiële participatie voor de energietransitie onderkend. Aangezien vele plannen voor wind- en zonneparken in de pijplijn zitten, kunnen de komende tijd talrijke nieuwe omgevingsfondsen worden verwacht. Pecunia non olet?

Het bovenwettelijke karakter van het omgevingsfonds brengt voordelen met zich. Zo hebben de betrokken partijen de vrijheid om te kiezen voor de gewenste vorm van financiële participatie en de invulling ervan aan te passen aan de lokale omstandigheden. Echter, er schuilen ook zwaarwegende nadelen in het ontbreken van een (wettelijke) regeling.

Het gebrek aan normering bij de totstandkoming van omgevingsfondsen leidt tot grote verschillen in de omvang van omgevingsfondsen en blijkt een bron van conflicten. In de praktijk lijkt met name de vraag wie de (ultieme) zeggenschap heeft of zou moeten hebben te leiden tot controverse. De problematiek bij Windpark De Drentse Monden en Oostermoer, waarbij de 'windboeren' willen meepraten over de verdeling van de gelden, vormt hiervan een sprekend voorbeeld. Ook de moeilijkheden bij Windpark Geefsweer om tot een regeling te komen, lijken te zijn veroorzaakt door het gebrek aan richting bij de totstandkoming van omgevingsfondsen. Het Klimaatakkoord, de Participatiewaaier en de gedragscodes van de energiebranche geven geen oplossingen voor dergelijke patstellingen. Daarnaast hebben omwonenden soms nauwelijks zeggenschap over de verdeling van gelden uit een omgevingsfonds, terwijl het Klimaatakkoord voorschrijft dat besluitvorming hierover door de 'omgeving' geschiedt.

Is het omgevingsfonds eenmaal in werking, dan kan een ander nadeel ontstaan, namelijk het ontbreken van waarborgen voor omwonenden. De wijze waarop het beheer van een omgevingsfonds is opgezet, heeft verstrekkende consequenties voor de toepasselijkheid van bestuursrechtelijke normen die transparantie, toezicht en rechtsbescherming garanderen. Doorslaggevend is of de beherende entiteit kan worden aangemerkt als bestuursorgaan. Dit komt slechts in een uitzonderlijk geval voor. Uit onze verkenning is gebleken dat omge-

85. Art. 5 lid 4 Reglement Omgevingsfonds Windpark Nijmegen-Betuwe. vingsfondsen in de praktijk meestal worden beheerd door stichtingen. Deze stichtingen zullen praktisch nooit kunnen worden aangemerkt als bestuursorgaan, omdat niet zal worden voldaan aan het inhoudelijke en financiële vereiste uit de rechtspraak. Dit betekent dat publiekrechtelijke waarborgen niet van toepassing zijn bij de verdeling van de gelden uit omgevingsfondsen. Hoewel er jaarlijks tienduizenden tot wel honderdduizenden euro's in omgevingsfondsen omgaan, waaronder incidenteel publieke gelden, zijn eisen voor transparantie, toezicht en rechtsbescherming afhankelijk van de inhoud van de statuten en het fondsreglement.

Statutaire of reglementaire verplichtingen hiertoe zijn echter geenszins vanzelfsprekend gebleken. Over een gebrek aan transparantie ten aanzien van de verdelingsregels hebben de omwonenden van Zonnepark Stadskanaal al geklaagd. Omwonenden die niet begrijpen hoe een verdeling tot stand is gekomen, moeten maar zien of zij een motivering krijgen. Indien omwonenden het oneens zijn met de verdeling, hebben zij vervolgens geen mogelijkheden om bezwaar te maken of een vordering in te stellen. Een geschillenregeling bieden de onderzochte fondsreglementen evenmin.

Het risico bestaat dat het opgebouwde draagvlak voor het wind- of zonnepark gauw zal afbrokkelen. Om conflicten te voorkomen is van belang om bij het opstellen van de verdelingsregels, gedragscodes en het sluiten van overeenkomsten aandacht te besteden aan het inbouwen van waarborgen en het toekennen van (ultieme) zeggenschap. Daarnaast is meer onderzoek over de wenselijkheid van een (wettelijke) regeling van omgevingsfondsen en de verschillende juridische constructies van het beheer noodzakelijk. ${ }^{86}$ Ten slotte kan pas daadwerkelijk worden gesproken van financiële participatie, als zeggenschap en waarborgen voor omwonenden zijn verzekerd. Alleen dan staat een omgevingsfonds daadwerkelijk ten dienste van de omgeving.

86. Zie ook over de noodzaak van onderzoek naar de wenselijkheid van een wettelijke regeling Noordelijke Rekenkamer 2020, p. 11. 